\title{
Clinical and Echocardiographic Assessment of Patients with Dilated Cardiomyopathy
}

\author{
Aryal M
}

\begin{abstract}
Introduction: Cardiomyopathy is the disorder of the heart muscles which can be dilated, hypertrophic or restrictive type. Dilated cardiomyopathy is caused by genetic and non-genetic causes but many of the causes are still not known. Echocardiography is an important imaging technique to diagnose and manage dilated cardiomyopathy. Aims: This study aims to assess the clinical and echocardiographic findings among patients with dilated cardiomyopathy. Methods: This is a cross-sectional, observational study conducted in Nepalgunj Medical College from January 2021 to June 2021. A total of 61 patients with dilated Cardiomyopathy were enrolled after obtaining written informed consent. Clinical examination and echocardiographic findings were recorded and data analysis was done using Statistical Package for Social Sciences. Results: The participants included 31 men and 30 women with dilated cardiomyopathy. The mean age of the participants was $58.49 \pm 15.46$ years. The most common complaint was shortness of breath $84.5 \%$ and the most common clinical presentation was bilateral basal crepitation $98.4 \%$. The patients mostly had diastolic left ventricle internal diameter of 5.5-6 cm and ejection fraction of 21-30\%. Mitral regurgitation was observed among most $58(95.1 \%)$ of the patients. Conclusion: This study concludes that shortness of breath and bilateral basal crepitation are the most common presentation. Left ventricle dilation, reduced ejection fraction and mitral regurgitation are seen among majority of the patients.
\end{abstract}

Keywords: Crepitation, Dilated Cardiomyopathy, Echocardiography, Ejection Fraction, Shortness of Breath

Author:

1. Dr. Madhu Aryal

Address for Correspondence:

Dr. Madhu Aryal

Department of Internal Medicine

Nepalgunj Medical College and Teaching Hospital

Nepalgunj, Banke

Email: dr.madhuaryal@gmail.com

\section{INTRODUCTION}

Disorders of heart muscles are termed as cardiomyopathies. It can be classified into dilated, hypertrophic or restrictive type. ${ }^{1}$ Dilated cardiomyopathy (DCM) presents usually with enlargement of the left ventricle and its weak contraction due to genomic and non-genomic causes. The non-genetic causes included valve disorders, hypertension, toxins, infectious and inflammatory causes. ${ }^{2}$

A large portion of the cause of DCM is yet, unknown. Following coronary artery disease (CAD) and hypertension, DCM is the third common cause of cardiac failure. About 5 to 8 cases of DCM is estimated to occur in 100,000 people annually. It is one of the primary conditions that can lead to sudden death in the younger population. It is also a frequent condition requiring heart transplantation. ${ }^{3}$ Echocardiography is a commonly requested imaging technique to determine the size, mass and function of the heart. ${ }^{4}$ Echocardiography plays a vital role in diagnosis and management of DCM. ${ }^{5}$ The primary objective of this study is to assess the clinical and echocardiographic findings among DCM patients.

\section{METHODS}

A quantitative, cross sectional, observational study was conducted in Internal Medicine, Out Patient Department, Nepalgunj Medical College. The study took place from January 2021 to June 2021. A total of 61 patients diagnosed with DCM by history, clinical presentation and echocardiographic findings were recruited by convenience sampling after informed written consent was obtained. Pediatric population were excluded from the study.

Clinical examination of the patients with DCM was done. Echocardiography was done by a cardiologist using Alpinion Diamond. Mitral regurgitation, aortic regurgitation, tricuspid regurgitation, left ventricular size, right ventricular size, left atrial size, right ventricular size, ejection fraction, pericardial effusion and diastolic dysfunction were recorded. Internal diastolic dimension of the left ventricle equal to or more than $5.5 \mathrm{~cm}$ was considered dilated and ejection fraction (EF\%) lower than $50 \%$ was recorded as decreased.

Statistical Package of Social Science (SPSS) software version 25 was used for data analysis. The categorical variables were expressed in frequency and percentage whereas, numerical variables were expressed in mean and standard deviation. T-test was applied to determine the difference in left ventricle diameter and ejection fraction among male and female participants. Analysis of Variance (ANOVA) was used 
to determine the difference in ejection fraction according to age categories. A P-value of $<0.05$ was considered statistically significant.

\section{RESULTS}

A total of 61 patients diagnosed as DCM were recruited from OPD of Internal Medicine of Nepalgunj Medical College, Nepalgunj. The participants included 30 females and 31 males.

\begin{tabular}{ccc}
$\begin{array}{c}\text { Age } \\
\text { (years) }\end{array}$ & $\mathbf{N}$ \\
$\leq 30$ & $(\%)$ & 5 \\
& $31-60$ & $(8.2 \%)$ \\
& 25 \\
$>60$ & $(41 \%)$ \\
& 31 \\
Total & $(50.8 \%)$ \\
$N(\%)=$ frequency (percentage) & 61 \\
\hline
\end{tabular}

\section{Table I: Distribution of patients according to age}

The ages of the participants ranged from 18 to 91 years with a mean age of $58.49 \pm 15.46$ years. The patients with DCM were mostly above the age of 60 years, $31(50.8 \%)$ as shown in table I.

\begin{tabular}{|c|c|c|c|}
\hline Complaints & N (\%) & Clinical Signs & N (\%) \\
\hline Shortness of Breath & $\begin{array}{c}54 \\
(88.5 \%)\end{array}$ & $\begin{array}{l}\text { Bilateral basal } \\
\text { crepitation }\end{array}$ & $\begin{array}{c}60 \\
(98.4 \%)\end{array}$ \\
\hline Palpitation & $\begin{array}{c}31 \\
(50.8 \%)\end{array}$ & $\begin{array}{l}\text { Raised Jugular } \\
\text { Venous Pressure }\end{array}$ & $\begin{array}{c}6 \\
(9.8 \%)\end{array}$ \\
\hline Fatigue & $\begin{array}{c}7 \\
(11.5 \%)\end{array}$ & $\begin{array}{c}\text { Tender } \\
\text { hepatomegaly }\end{array}$ & $\begin{array}{c}10 \\
(16.4 \%)\end{array}$ \\
\hline Chest discomfort & $\begin{array}{c}3 \\
(4.9 \%)\end{array}$ & $\begin{array}{l}\text { Bilateral pedal } \\
\text { edema }\end{array}$ & $\begin{array}{c}24 \\
(39.3 \%)\end{array}$ \\
\hline Cough & $\begin{array}{c}21 \\
(34.4 \%)\end{array}$ & & \\
\hline
\end{tabular}

Table II: Distribution of complaints and clinical signs among the patients

Table II. depicts that the most common complaint during presentation was shortness of breath 54(88.5\%) and the most common clinical sign during examination was bilateral basal crepitation 60(98.4\%).

\begin{tabular}{|c|c|c|c|}
\hline $\begin{array}{l}\text { Left ventricle } \\
\text { diameter }\end{array}$ & $\begin{array}{l}N \\
(\%)\end{array}$ & $\begin{array}{l}\text { Ejection } \\
\text { Fraction }\end{array}$ & $\begin{array}{c}N \\
(\%)\end{array}$ \\
\hline$<5.5 \mathrm{~cm}$ & $\begin{array}{c}1 \\
(1.6 \%)\end{array}$ & $>50 \%$ & $\begin{array}{c}2 \\
(3.3 \%)\end{array}$ \\
\hline $5.5-6 \mathrm{~cm}$ & $\begin{array}{c}23 \\
(37.7 \%)\end{array}$ & $41-50 \%$ & $\begin{array}{c}7 \\
(11.5 \%)\end{array}$ \\
\hline $6.1-6.5 \mathrm{~cm}$ & $\begin{array}{c}11 \\
(18 \%)\end{array}$ & $31-40 \%$ & $\begin{array}{c}12 \\
(9.7 \%)\end{array}$ \\
\hline $6.6-7.0 \mathrm{~cm}$ & $\begin{array}{c}14 \\
(23 \%)\end{array}$ & $21-30 \%$ & $\begin{array}{c}32 \\
(52.5 \%)\end{array}$ \\
\hline$>7 \mathrm{~cm}$ & $\begin{array}{c}12 \\
(98.4 \%)\end{array}$ & $15-20 \%$ & $\begin{array}{c}8 \\
(13.1 \%)\end{array}$ \\
\hline Total & $\begin{array}{c}61 \\
(100 \%)\end{array}$ & Total & $\begin{array}{c}61 \\
(100 \%)\end{array}$ \\
\hline
\end{tabular}

Table III: Diastolic diameter of the left ventricle and ejection fraction among the participants

The majority of the patients $23(37.7 \%)$ had left ventricular diastolic diameter of $5.5-6 \mathrm{~cm}$ and 32(52.5\%) patients had an ejection fraction of $21-30 \%$ as illustrated in table III. The mean left ventricle size was $6.41+0.62 \mathrm{~cm}$, mean left atrium size was $4.74 \pm 0.59 \mathrm{~cm}$ and the mean ejection fraction was $26.23 \pm 9.6 \%$. Right ventricle and right atrium were dilated among $32(52.5 \%)$ patients. Pericardial effusion was observed among 6(9.8\%) participants.

\begin{tabular}{|c|c|c|c|}
\hline Grading & $\begin{array}{c}\text { Mitral } \\
\text { Regurgitation } \\
\text { N (\%) }\end{array}$ & $\begin{array}{c}\text { Aortic } \\
\text { Regurgitation } \\
\text { N (\%) }\end{array}$ & $\begin{array}{c}\text { Tricuspid } \\
\text { Regurgitation } \\
\text { N (\%) }\end{array}$ \\
\hline Non & $\begin{array}{c}3 \\
(4.9 \%)\end{array}$ & $\begin{array}{c}26 \\
(42.6 \%)\end{array}$ & $\begin{array}{c}7 \\
(11.5 \%)\end{array}$ \\
\hline Trace & $\begin{array}{c}3 \\
(4.9 \%)\end{array}$ & $\begin{array}{c}7 \\
(11.5 \%)\end{array}$ & $\begin{array}{c}4 \\
(6.6 \%)\end{array}$ \\
\hline Mild & $\begin{array}{c}19 \\
(31.1 \%)\end{array}$ & $\begin{array}{c}22 \\
(36.1 \%)\end{array}$ & $\begin{array}{c}26 \\
(42.6 \%)\end{array}$ \\
\hline Moderate & $\begin{array}{c}25 \\
(41 \%)\end{array}$ & $\begin{array}{c}6 \\
(9.8 \%)\end{array}$ & $\begin{array}{c}19 \\
(31.1 \%)\end{array}$ \\
\hline Severe & $\begin{array}{c}11 \\
(18 \%)\end{array}$ & - & $\begin{array}{c}5 \\
(8.2)\end{array}$ \\
\hline Total & $\begin{array}{c}61 \\
(100 \%)\end{array}$ & & \\
\hline
\end{tabular}

Table IV: Distribution of valvular regurgitation among the participants

Mitra valve regurgitation was the most frequently observed valvular regurgitation 58(95.1\%), followed by tricuspid regurgitation $54(88.5 \%)$ and aortic regurgitation 35(57.4\%) as shown in table IV. Only, 3(4.9\%) of the patients had left ventricular diastolic dysfunction grade one. 


\begin{tabular}{|c|c|c|c|c|c|}
\hline Gender & N (\%) & $\begin{array}{l}\text { Left ventricle } \\
\text { diameter }\end{array}$ & $\begin{array}{l}\mathrm{P}- \\
\text { value }\end{array}$ & $\begin{array}{l}\text { Ejection } \\
\text { Fraction }\end{array}$ & $\begin{array}{c}P \text { - } \\
\text { value }\end{array}$ \\
\hline & & Mean \pm SD & & Mean \pm SD & \\
\hline Male & $\begin{array}{c}31(51.67 \\
\%)\end{array}$ & $6.54 \pm 0.58$ & & $25.16 \pm 9.7$ & \\
\hline Female & $\begin{array}{c}30(48.33 \\
\%)\end{array}$ & $6.27 \pm 0.64$ & 0.90 & $27.33 \pm 9.54$ & 0.38 \\
\hline
\end{tabular}

Table V: Left ventricular diameter and ejection fraction according to gender

No significant difference was observed in left ventricle diameter and ejection fraction among the male and female participants as shown in table $\mathrm{V}$.

\begin{tabular}{ccc}
$\begin{array}{cc}\text { Age in years } \\
\text { Mean } \pm \text { SD }\end{array}$ & Ejection fraction & P- value \\
$\leq 30$ & $30 \pm 10$ & \\
$31-60$ & $24.8 \pm 11$ & \\
$>60$ & $26.77 \pm 8.3$ & \\
\hline Total & $26.33 \pm 9.6$ &
\end{tabular}

$\mathrm{SD}=$ standard deviation; $\mathrm{p}$-value $=$ probability value

Table VI: Comparison of ejection fraction according to age

No significant difference was observed in ejection fraction according to age categories as illustrated in table VI.

\section{DISCUSSION}

Though the prognosis in patients with DCM has improved in the recent years, the outcome still remains uncertain. ${ }^{7}$ In this study we assessed the clinical and echocardiographic findings among DCM patients.

In this study most of the patients with DCM were males which was similar to various studies done in the past. $6,8,9$ Similar to this study, a study conducted by Kafle RC et al also had the majority of patients $208(54 \%)$ with DCM above the age of 60 years. ${ }^{9} \mathrm{~A}$ study conducted by Deshmukh $\mathrm{A}$ et al also observed similar findings with majority of the patients $(48 \%)$ with DCM above the age of 60 years. ${ }^{8}$

In similarity to this study, Hoque SJ et al also observed shortness of breath as the most common presenting complaint $45(90 \%)$ and bilateral basal crepitation as the most common clinical finding $45(90 \%) .{ }^{10} \mathrm{~A}$ study conducted by Sonowal $\mathrm{N}$ et al also observed 22(70.97\%) presented with shortness of breath. ${ }^{11}$

Similar to this study, Thapa et al. also observed that most of the patients $36(55 \%)$ had diastolic left ventricle internal diameter of $5.5-6 \mathrm{~cm}$. The ejection fraction observed among the majority patients $24(36.92 \%)$ was also $21-30 \%{ }^{6}$ In contrast to this study, Kafle RC et al observed the majority of the patients $160(40 \%)$ had an ejection fraction of $36-40 \% .{ }^{9}$ Similar to this study, Thapa et al also observed $18 \%$ of the patients with DCM had right atrium and ventricles dilated, however the finding in this study was higher (52.5\%). ${ }^{6}$ In similarity to this study, Kafle RC et al also observed most of the patients $338(84.5 \%)$, had mitral regurgitation (MR) and among them moderate MR (168)42\% was most frequent. However, in contrast to this study, tricuspid regurgitation (TR) was seen among only $246(61.5 \%)$ which was lower than this study 54(88.5\%) and moderate TR was most frequent $124(31 \%)$ whereas, mild TR was more frequent in this study $26(42.6 \%) .{ }^{9}$

\section{LIMITATIONS}

This is a cross sectional study and does not allow to determine the cause and effect. The study was conducted in a single center and convenience sampling method was used which may not represent the general population.

\section{CONCLUSION}

This study concludes that dilated cardiomyopathy presents mainly with complaints of shortness of breath and clinical presentation of bilateral basal crepitation. Echocardiography shows dilation of left ventricle, reduced ejection fraction and mitral regurgitation in majority of the patients.

\section{REFERENCES}

1. Schultheiss H-P, Fairweather D, Caforio ALP et al. Dilated Cardiomyopathy. Nat Rev Dis Primer. 2019;5(1):1-19.

2. McNally EM, Mestroni L. Dilated Cardiomyopathy. Circ Res. 2017;121(7):731-48.

3. Rubis P. The Diagnostic Work Up of Genetic and Inflammatory Dilated Cardiomyopathy. E-Journal of Cardiology Practice. 2015;13(19):1-8.

4. Lang RM, Bierig M, Devereux RB et al. Recommendations for Chamber Quantification: A Report from the American Society of Echocardiography's Guidelines and Standards Committee and the Chamber Quantification Writing Group, Developed in Conjunction with the European Association of Echocardiography, a Branch of the European Society of Cardiology. J Am SocEchocardiogr. 2005;18(12):1440-63.

5. Pinamonti B, Abate E, De Luca A, Finocchiaro G, Korcova R. Role of Cardiac Imaging: Echocardiography. In: Sinagra G, Merlo M, Pinamonti B, editors. Dilated Cardiomyopathy: From Genetics to Clinical Management. Cham, Switzerland: Springer; 2019.p.83-112.

6. Thapa R, KC K, Khatri R et al. An Echocardiographic Evaluation of Dilated Cardiomyopathy in a Tertiary Care Hospita. J Nepal Med Assoc. 2018;56(214):33-6.

7. Merlo M, Caiffa T, Gobbo M, Adamo L, Sinagra G. Reverse Remodeling in Dilated Cardiomyopathy: Insights and Future Perspectives. IJC Heart Vasc. 2018;18(2018):52-7.

8. Deshmukh A, Deshmukh A, Deshmukh G, Garg P. A Pilot Study of Dilated Cardiomyopathy (DCM) in western Uttar 
Pradesh India: A Four Year Review. Medico-Leg Update. 2011;11(1):1-3.

9. Kafle RC, Paudel N, Sharma D, Alurkar VM. Electrocardiographic Profile of Dilated Cardiomyopathy in Patients Attending a Tertiary Care Hospital of Western Nepal. J UniversColl Med Sci. 2018;6(1):40-5.

10. Hoque SJ, Rahman A, AlamMdZ, Irfan SMR. Clinical Profile of Patients with Idiopathic Dilated Cardiomyopathy in a Tertiary Care Hospital of Bangladesh. Bangladesh Crit Care J. 2019;7(2):86-9.

11. Sonowal N, Vanamali DR. Clinical Profile of Patients with Dilated Cardiomyopathy in a Tertiary Care Center in North East India. J Evol Med Dent Sci. 2014;3(30):8378-86. 